\title{
The Effects of Top-down/Bottom-up Processing and Field-dependent/Field-independent Cognitive Style on Iranian EFL Learners' Reading Comprehension
}

\author{
Azar Hosseini Fatemi \\ English Department, Ferdowsi University of Mashhad, Iran \\ Vahideh Sadat Vahedi (corresponding author) \\ Islamic Azad University, Qaenat Branch, Qaenat, Iran \\ Zari Sadat Seyyedrezaie
}

Department of English Language Teaching, Aliabad Katoul Branch, Islamic Azad University, Aliabad Katoul, Iran

\begin{abstract}
The present study aimed at exploring the effects of top-down/bottom-up processing and field-dependent/field-independent cognitive style on Iranian EFL learners' reading comprehension. That is, it was attempted to find firstly, whether FI learners would perform better when taught through top-down or bottom-up reading instruction model; secondly, whether FD learners would perform better when taught through top-down or bottom-up reading instruction model. Two intact classes including 40 Iranian freshmen EFL students with the same level of reading proficiency tested through reading section of TOEFL test participated in this study. One class was randomly assigned to top- down reading instruction model and the other to bottom- up approach. The study consisted of three stages. At first stage, Group Embedded Figure Test (GEFT) was administered to determine the distribution of subjects along the spectrum of FD/ FI in each group. Then, the treatment was run and finally, both groups received a reading comprehension posttest. The data were analyzed using two independent samples t-tests. The results revealed that FI learners outperform their FD counterparts in bottom- up group. Moreover, the results showed that FD learners were more successful than FI ones when taught through top- down reading instruction model. In light of these findings, the researchers offered recommendations for further research and for EFL reading educators.
\end{abstract}

Index Terms-field-independent, field-dependent, top-down/bottom-up instructional model, reading comprehension

\section{INTRODUCTION}

The most important skill for second language learners in academic context is reading (Lynch\& Hudson, 1991, cited in Grabe, 1991). Thus, it can be concluded that perhaps the most fundamental skill to be taught in Iranian academic context, where English is taught as a foreign language, is reading comprehension. Therefore, there is a need for EFL teachers to know about the different approaches they can use while teaching reading comprehension.

Top-down and bottom-up processing are two approaches discussed in reading research and literature (Abraham, 1985; Field, 2004). Top-down processing, According to Paran (1996), top-down processing also known as concept-driven model emphasizes on contextual factors such as socio-cultural knowledge and proceeds from whole to part. In other words, top-down processing happens when the reader activates his/her world knowledge to facilitate comprehending the text. On the other hand, in bottom-up reading model, the written or printed text is the centre of attention and reading proceeds from part to the whole. Readers usually use their knowledge of lexical items, structural points and phonological patterns to decode the text meaning. According to Gough (1972), in bottom-up model, the reading process proceeds in serial fashion, from letter to sound, to words, to meaning.

Due to the importance and significance of top-down and bottom-up processing as revealed by previous studies (e.g. Abraham, 1985; Field, 2004; Tsui \& Fullilove, 1998); a great deal of studies have been conducted to investigate the effect of top-down and/or bottom-up processing in learning different skills, and their application in EFL classroom. One of the most interesting features discussed in relation to top-down and bottom-up processing is cognitive style.

The field-independence/field-dependence (FI/FD) cognitive style has received the greatest attention in second/foreign language research. Zhang (2004) defined FI/FD as a reflection of the extent to which an individual uses external or internal cues for performing tasks. FI/FD is typically referred to as a variable of cognitive style - a pervasive, stable, and bipolar characteristic affecting the process of perception, thinking, and problem solving (Chapelle, 1988). A FI person perceives analytically, analyzes and isolates relevant details, detects patterns, and critically evaluates data; while FD 
one perceives holistically, tends to get lost in the stimuli and is unable to distinguish salient points. FI/FD describes two contrasting ways of processing information along a continuum from extreme field-dependence to extreme field-independence. "FI subjects trust internal cues, and this is associated with a greater aptitude for restructuring, i.e. for imposing organization on received information. FD subjects, on the other hand, place their trust in external cues, and tend to accept percents of symbolic representations at face value" (Tinajero \& Paramo, 1997, p. 199).

The studies conducted in the domain of cognitive styles (field-dependent and/or field-independent) have considered the effect of cognitive styles on academic achievement (Dwyer \& Moore, 1995); the relationship between attitudes toward computers and cognitive styles (Altun, 2003); and the effect of cognitive styles on reading comprehension tasks (Davey, 1990).

Although some studies have been conducted on top-down / bottom-up processing, and cognitive styles separately, relatively few efforts have been made in considering both variables in learning specific skill. This study attempted to fill this gap and find whether there are any statistically significant differences between reading comprehension scores of field-dependent and field-independent learners who are exposed to top-down vs. bottom-up reading instruction model.

To fulfill the purpose of this study, the following research questions were addressed:

1. Is there any statistically significant difference in reading comprehension scores of field-dependent and field-independent learners who are exposed to top-down reading instruction model?

2. Is there any statistically significant difference in reading comprehension scores of field-dependent and field-independent learners who are exposed to bottom-up reading instruction model?

\section{LITERATURE REVIEW}

A reading model is a theory of what is going on in the reader's eyes and mind during reading and comprehending (or miscomprehending) a text" (Davies, 1995, cited in Škudienė, 2002, p. 59). Models of the reading process which are called top-down and bottom-up try to explain and predict reading behavior. They are the bases on which reading instructions are built.

According to Swaffer, Arans, and Byrnes (1991), a top-down model which focuses on the importance of background knowledge, builds global comprehension while a bottom-up model which emphasizes the linguistic clues, builds literal comprehension of a text.

Top-down models of reading seems not to be useful for language learners at elementary levels because, as Carrell and Eisterhold (1983) argue, "knowledge of a minimum of 5000 words is essential to make top-down processing possible" (Škudienè, 2002, p. 59). In contrast, bottom-up models cannot be useful at the advanced language learners because students have the capability to decode graphical input automatically (Škudienè, 2002)

Some studies have focused on the notion of top-down/ bottom-up processing in academic context (Abraham, 1985; Field, 2004). Wasilewski (2009) conducted a study to reveal the importance of reading process and strategies utilized by the readers of a foreign language when processing the written text. Moreover, Škudiené (2002) examined which model of reading (top-down or/ bottom-up) is emphasized during pre-, while-, and post-reading activities for intermediate English language learners. The results of this research exhibited that most of the pre-reading and while-reading activities were based on top-down models while post-reading instruction was interactive with more emphasis on bottom-up models.

Top-down or bottom-up instruction has close relationship with cognitive style of learning. According to Xu (2011), cognitive learning styles include "focuser and scanner, serialists and holists, divergent and convergent thinkers, field-dependence (global leaner) and field-independence (analytic learner)" (p.414). Among these pairs, the most important one is field independence and field dependence, which has been explored greatly in relation to L2 learning.

In another study, Dwyer and Moore (1995) examined the effect of cognitive style on students' achievement. The result showed the superiority of the field independent learners on tests measuring different educational objectives. They concluded that cognitive style had a significant association with students' academic achievement.

The performance of children with different FD/FI cognitive styles in tasks of attentional functioning was examined by Guisande, Pramo, Tinajero, and Almeida (2007). They found that FI children displayed better performance than FD children on all tests except the Digits Forward Test.

Also, in a study done by Davey (1990), 56 field-dependent and 55 field-independent students in grades six through eight were evaluated on reading comprehension tasks which were different in memory load and cognitive restructuring requirements. The results showed that field-independent readers performed better than field-dependent readers on tasks with high memory demands and requirements for efficient restructuring.

Moreover, Yaghoubi (1994) conducted a research aimed at examining whether, and to what extent, there was a relationship between FD/FI cognitive styles and foreign language proficiency of Iranian EFL students. The study revealed that FI learners outperformed FD ones in language classes, and that FI cognitive style was conducive to language learning. Accordingly, Liu and Reed (1994) examined different learning strategies used by sixty-three field-independent (FI) and field-dependent (FD) international college students in a hypermedia assisted language learning setting and found that FI was conducive to language learning. In another study, Fehrenbach (1994) compared the cognitive styles of thirty gifted and thirty average secondary-level readers and found that both groups used the same reading strategies but with differing frequencies. In his study, Shalbafan (1996) noticed that previous studies concerning 
the relationship between field dependence/field independence cognitive style and second/foreign language learning (S/FLL) had demonstrated that, while field independent individuals were successful at analytic and deductive language learning activities, field dependent learners showed their superiority at induction and communication. Shalbafan (1996) aimed at investigating whether the findings of previous research could be generalized to Iranian EFL learners' writing ability. The results indicated that, regarding the form of a writing task, field independent students outperformed their field dependent counterparts. The results also revealed that regarding the content of writing, field dependent students performed better than field independent students.

\section{METHOD}

\section{A. Participants}

The participants of the present study were 80 Iranian male and female EFL freshman students chosen out of 100 students based on their scores in reading section of TOEFL test. The EFL students were from two Islamic Azad universities. The participants having passed reading posttest 1 and 2 shared the same linguistic background. The participants aged from 18 to 24 years old. In this study, the participants were randomly assigned into two groups. There were 40 students in one group benefiting from top-down reading instruction model and 40 students in the other group benefiting from bottom-up reading instruction one. Classes were held 2 hours a week for the duration of 4 weeks. All classes had the same material, namely the same reading texts were used for both groups.

\section{B. Instrumentation}

a. Reading Proficiency Test

In order to determine the reading proficiency level of the participants for the sake of homogeneity, the reading section of TOEFL test was used.

b. The Group Embedded Figure Test (GEFT)

To identify participants' FD/ FI cognitive style, the GEFT instrument developed by Witkin, Oltman, Raskin, and Karp (1971) was used. The reported reliability of GEFT is 0.89 (Foel \& Fritz, 1994). " Among all the various instruments that have been introduced for assessing the cognitive style of field-dependence/ independence, this test has been the most common instrument applied by the researchers" (Alavi \& Kavyanpanah, 2009; Yousefi, 2011, cited in Hamed Mahvelati \& Mukundan, 2012, p. 108).

This test consists of three sections; the first section includes 7 figures and is designed for practice. The second and third section each has 9 figures. The students were required to recognize the common geometric shapes hidden in a larger complex design. The cut- off point was determined based on Case's (1974, cited in Hamed Mahvelati \& Mukundan, 2012) criteria. That is, the students scored 1/4 SD below the group mean score were accounted as fielddependent and those scored 1/4 SD above the group mean score were called field- independent. The learners whose mean score was between 1/4 SD below and 1/4 SD above the mean were labeled as field- intermediate subjects and thus were excluded.

c. Reading Comprehension Test

A reading comprehension test was used in this study, one as a pretest to assure the equality of two groups prior to the instructional treatment and the second time, as post- test to determine the impact of two instructional treatments after their implementation.

\section{Procedure}

In the present study, the data were collected through different stages. At the beginning of the experiment, the reading section of a TOEFL test was administered to determine the learners' level of reading proficiency and select highly homogeneous students. On the basis of this test, two groups of 40 participants were selected, one group received top-down and the second one bottom-up reading instruction model. Then, the participants were asked to answer GEFT to determine their distribution along the continuum of FD/ FI. Moreover, the reading comprehension posttest was preadministered to assure that the learners in each group had the same reading proficiency level. During the experiment, the two groups received the instruction for 4 weeks, which was aligned with the ongoing university program. Both groups were taught by the same teacher since the teachers' individual and methodological characteristics might affect the results. After the tutorial, the reading comprehension test was administered to the two groups (top- down/ bottomup). The results of this posttest, once gathered and analyzed statistically, provided the answer to the proposed research questions.

\section{Data Analysis}

In the present study, students' cognitive style (FD/ FI) and the reading instruction models (top- down vs. bottom- up) were considered as independent variables; while the participants' reading comprehension scores were accounted as dependent variable. Through using descriptive and inferential statistics, the data were analyzed. To address the first and second research questions, two independent samples t- tests were used.

\section{Results}


The current study attempted to investigate the effects of top-down/bottom-up processing and field-dependent/field-independent cognitive style on Iranian EFL learners' reading comprehension.

To answer the research questions, after scoring the tests and tabulating the scores for each subject, the data were put under a series of statistical analysis.

First of all, to show the distribution of participants along the spectrum of FI/ FD in each group, the results of the administration of GEFT are presented in Table 1.

TABLE 1:

THE DISTRIBUTION OF PARTICIPANTS ALONG THE SPECTRUM OF FI/FD

\begin{tabular}{|l|l|l|l|}
\hline \multicolumn{2}{|c|}{ Group 1 ( top- down reading instruction) } & Group 2 ( bottom- up reading instruction) \\
\hline FI & FD & FI & FD \\
\hline 22 & 18 & 17 & 23 \\
\hline
\end{tabular}

Based on the above classification, the participants were divided into two main groups (top-down/bottom-up reading instruction), each group included field independent/field-dependent learners.

Additionally, in order to show that subjects were homogeneous in two main groups and there was no significant difference between them prior to the experiment, the reading achievement test was pre- administered before they stated the experiment. The results of Homogeneity of Variance for each group are summarized in Table 2.

TABLE 2

TEST OF HOMOGENIETY OF VARIANCES FOR TOP- DOWN/ BOTTOM- UP GROUP

\begin{tabular}{|l|l|l|l|l|}
\hline & Levene Statistic & df1 & df2 & Sig. \\
\hline Top- down group & .002 & 1 & 38 & .967 \\
Bottom- up group & .623 & 1 & 38 & .435 \\
\hline
\end{tabular}

As it is clear, the performance of FI subjects was not statistically different from the FD ones in top- down reading group $(\mathrm{P}=.96>.05)$ and bottom- up reading group $(\mathrm{P}=.43>.05)$. This means that subjects in each group started out the experiment with equivalent reading background knowledge.

To answer the first research question of the study stating that whether there is any statistically significant difference in reading comprehension scores of field-dependent and independent learners who are exposed to top-down reading instruction, the participants' scores on the reading comprehension posttest were gathered and tabulated. Table 3 and Figure 1 represent a better picture of the performance of FD/ FI learners in top- down group.

TABLE 3

DESCRIPTIVE STATISTICS OF THE PERFORMANCE OF FD/FI LEARNERS IN TOP DOWN READING GROUP

\begin{tabular}{|c|c|c|c|c|c|c|c|c|}
\hline & \multirow[b]{2}{*}{$\mathrm{N}$} & \multirow[b]{2}{*}{ Mean } & \multirow{2}{*}{$\begin{array}{l}\text { Std. } \\
\text { Deviation }\end{array}$} & \multirow[b]{2}{*}{ Std. Error } & \multicolumn{2}{|c|}{$95 \%$ Confidence Interval for Mean } & \multirow[b]{2}{*}{ Minimum } & \multirow[b]{2}{*}{ Maximum } \\
\hline & & & & & Lower Bound & Upper Bound & & \\
\hline $\begin{array}{l}\text { field independence } \\
\text { field dependence } \\
\text { Total }\end{array}$ & $\begin{array}{l}22 \\
18 \\
40\end{array}$ & $\begin{array}{l}10.90 \\
12.44 \\
11.60\end{array}$ & $\begin{array}{l}1.90 \\
2.09 \\
2.10\end{array}$ & $\begin{array}{l}.40 \\
.49 \\
.33\end{array}$ & $\begin{array}{l}10.06 \\
11.40 \\
10.92\end{array}$ & $\begin{array}{l}11.75 \\
13.48 \\
12.27\end{array}$ & $\begin{array}{l}8.00 \\
9.00 \\
8.00\end{array}$ & $\begin{array}{l}14.00 \\
15.00 \\
15.00\end{array}$ \\
\hline
\end{tabular}

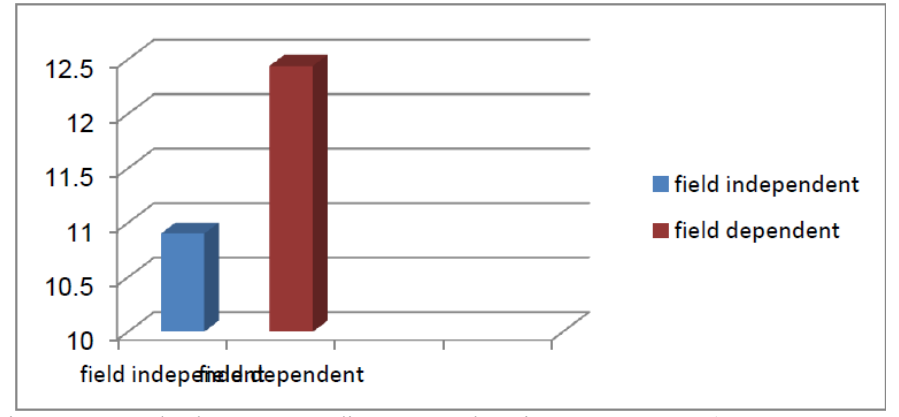

Figure 1. FD/FI learners' reading comprehension mean scores (top-down group)

According to the above descriptive results, the mean score of FI subjects differs from the FD ones'. To see whether this difference is statistically significant or not, an independent sample t- test was also run (Table 4).

TABLE 4

INDEPENDENT SAMPLES T-TEST FOR EQUALITY OF MEANS (TOP-DOWN GROUP)

\begin{tabular}{|c|c|c|c|c|c|c|}
\hline & \multicolumn{6}{|c|}{ t-test for Equality of Means( top-down group) } \\
\hline & \multirow[b]{2}{*}{$T$} & \multirow[b]{2}{*}{ Sig. (2-tailed) } & \multirow[b]{2}{*}{ Mean Difference } & \multirow[b]{2}{*}{ Std. Error Difference } & \multicolumn{2}{|c|}{$95 \%$ Confidence Interval of the Difference } \\
\hline & & & & & Lower & Upper \\
\hline reading score & 2.42 & 38.020 & -1.53 & .63 & -2.81 & -.25 \\
\hline
\end{tabular}


The results revealed that FD learners performed significantly better than FI ones in top- down reading instruction group $(\mathrm{t}=2.42, \mathrm{p}=.02<05)$.

To answer the second research question of the study stating that whether there is any statistically significant difference in reading comprehension scores of field-dependent and field-independent learners who were exposed to bottom-up reading instruction model, the descriptive statistics are shown in Table 5 and Figure 2.

TABLE 5

DESCRIPTIVE STATISTICS OF THE PERFORMANCE OF FD/ FI LEARNERS IN BOTTOM-UP READING GROUP

\begin{tabular}{|c|c|c|c|c|c|c|c|}
\hline & \multirow[b]{2}{*}{ Mean } & \multirow[b]{2}{*}{ Std. Deviation } & \multirow[b]{2}{*}{ Std. Error } & \multicolumn{2}{|c|}{$95 \%$ Confidence Interval for Mean } & \multirow[b]{2}{*}{ Minimum } & \multirow[b]{2}{*}{ Maximum } \\
\hline & & & & Lower Bound & Upper Bound & & \\
\hline $\begin{array}{l}\text { field independence } \\
\text { field dependence } \\
\text { Total }\end{array}$ & \begin{tabular}{l|l|}
17 & 13.05 \\
23 & 9.82 \\
40 & 11.20
\end{tabular} & $\begin{array}{l}1.02 \\
1.23 \\
1.97\end{array}$ & $\begin{array}{l}.24 \\
.25 \\
.31\end{array}$ & $\begin{array}{l}12.52 \\
9.29 \\
10.56\end{array}$ & $\begin{array}{l}13.58 \\
10.35 \\
11.83\end{array}$ & $\begin{array}{l}10.00 \\
8.00 \\
8.00\end{array}$ & $\begin{array}{l}14.00 \\
13.00 \\
15.00\end{array}$ \\
\hline
\end{tabular}

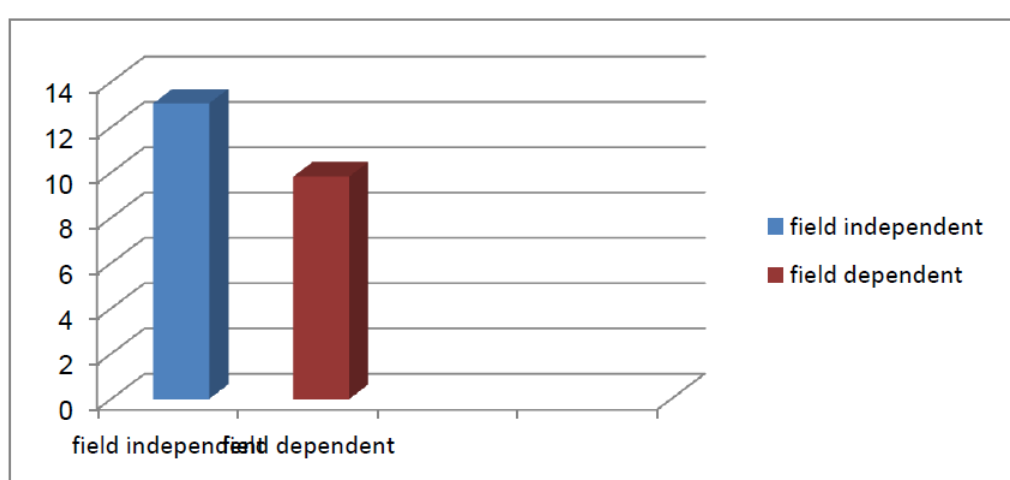

Figure 2. FD/FI learners' reading comprehension mean scores (bottom-up group)

On inspection of mean scores, one can infer that FD/ FI learners performed differently on reading achievement posttest. Its implication is that FI learners, as it is envisaged performed better than their FD counterparts. To check whether this difference is statistically significant, an independent sample t- test was performed (Table 6).

TABLE 6

INDEPENDENT SAMPLES T-TEST FOR EQUALITY OF MEANS (BOTTOM- UP GROUP)

\begin{tabular}{|c|c|c|c|c|c|c|}
\hline & & \multirow[b]{2}{*}{ Sig. (2-tailed) } & \multirow[b]{2}{*}{ Mean Difference } & \multirow[b]{2}{*}{ Std. Error Difference } & \multicolumn{2}{|c|}{$95 \%$ Confidence Interval of the Difference } \\
\hline & & & & & Lower & Upper \\
\hline reading score & 8.790 & 38.000 & 3.23274 & .36779 & 2.48819 & 3.97729 \\
\hline
\end{tabular}

The results indicated that there was a statistically significant difference between the mean scores of FD/ FI learners $(t=8.790)$ at the end of the experiment meaning that FI subjects did outperform the FD ones in the reading comprehension posttest.

\section{DISCUSSION}

The present study was an effort to investigate the possible effect that different types of reading instruction (top-down vs. bottom-up) and cognitive style of field dependence vs. field independence might have on learners reading performance during the course of the study. It attempted to empirically reveal that the type of instruction and classroom tasks can be very influential on accelerating learners' reading achievement especially when they are interwoven with individuals' cognitive style.

To achieve the purpose of the study, two research questions were raised at the onset.

Regarding the first research question, it was found that FD subjects outperformed their FI counterparts taught through top- down reading instruction. One justification can be that according to Brown (1994, p.160), FD learners have " the tendency to be dependent on the total field such that the parts embedded within the field is perceived more clearly as a unified whole". This is in line with top- down model which processing initiates with general knowledge of subject and continues to connect new information with previous ones. It might explain why FD learners seem to be less successful in tasks where concentration on small details is required.

This finding is consistent with Salmani Nodoushan's (2006) view that learners' cognitive style (FD/ FI) is crucial in benefitting from a specific teaching method. It is in sharp contrast with the theoretical view of those researchers who claim that there is no significant relationship between learners' cognitive style (FD/ FI) and L2 learning (Hamed Mahvelati \& Mukundan, 2012). In addition, the above finding is not also in line with Dyer and Osborne's (1999) view so far as they claim that the students' cognitive style of FD/ FI does not affect the effectiveness of teaching methods. 
The second result of this study showed that FI learners gained higher scores in reading achievement test in comparison with their FD counterparts when exposed to bottom- up reading instruction. one explanation can be that FI individuals have the ability of " perceiving a particular, relevant item or factor in a field of distracting factors" (Brown, 1994, p.160). Hence, FI learners can easily focus on details in a given task/ text. This might be one reason for the success of FI learners in bottom- up reading instruction where the brain begins with externally received information and analyze them in detail.

Concerning the superiority of FI learners to FD ones, the finding is consistent with some researchers' view (Clark \& Roof, 1988; Salmani Nodoushan, 2006) that FI learners perform better than FD ones in the learning tasks which require analysis and attention to details.

On the whole, the findings of the present study supported the findings of Sudzina (1993), Abu Romman (2005) researches. They reported that the academic achievements of learners can be enhanced when students' cognitive style is matched with the teaching methods. They are also consistent with Daoud's (2008) claim that the only factor affecting individuals' language learning is matching instruction with learners' cognitive style. However, the findings of the present study is not in line with El-Koumy's (2001) study which showed that students' achievement in reading comprehension increases when there is a mismatch between learners' cognitive style and teaching method.

Furthermore, it should be born in mind that the contradictory findings of some studies regarding the effectiveness of top- down and/ or bottom- up reading instruction can be due to the fact that learners' other individual differences have been neglected in most of these studies.

\section{CONCLUSION}

Concerning the first research question which dealt with investigating whether there is any statistically significant difference in reading comprehension scores of field-dependent and field-independent learners who were exposed to top-down reading instruction model, the obtained findings through independent samples t-test revealed that FD learners performed significantly better than FI ones in top-down reading instruction group.

This result supports the findings of Simonson (1985) and Miller (1997). In their studies, they found out FI learners were more proactive and usually had a strong self-concept, tended to solve problems through intuition and analyze data in details, As opposed to FD learners, who perceived objects as a whole.

Concerning the second research question, stating that whether there is any statistically significant difference in reading comprehension scores of field-dependent and field-independent learners who were exposed to bottom-up reading instruction model, an independent sample t-test was conducted. The result revealed that FI learners performed significantly better than FD ones in bottom-up reading instruction model.

Consistent with interactionist and cognitive views of language development, the above findings highlight the important role of attention. Put it simply, when a text is given to both field-dependent and field-independent learners, while the field-independent ones consider it analytically and focus on details, the field-dependent learners mostly pay attention to its global aspect and focus on comprehension of the content.

The findings of this study are in line with a study done by Shalbafan's (1996) who examined the relationship between field-dependence/field-independence cognitive style and second/foreign language learning revealing that while field-independent learners were successful at analytic and deductive language learning activities, field-dependent ones showed their advantage at induction, communication, and perception of materials holistically.

These findings seem to have important implications for L2 teachers and learners. As for teachers, if they know their students' cognitive style of field dependence/independence and learn more about the effective ways to help both groups improve their learning processes, they can change and adapt their teaching methods to the needs of the learners more effectively.

The findings of this study can also help language learners by encouraging them to learn more about their own individual cognitive styles and hence, improve their strengths and overcome their weaknesses.

There are some limitations need to be considered when interpreting the findings of this study. First, this study included only the Iranian EFL learners. A more comprehensive study including other nationalities and/or learners will enhance our understanding of the effects of top-down /bottom-up processing and cognitive styles on reading comprehension. Secondly, to increase the external validity of the study findings, replication is needed in different settings with diverse populations. It also needs to be emphasized that this study used only Witkin, Oltman, Raskin, and Karp (1971) FD/FI as an indicator of cognitive style. Other cognitive style inventories could be used to examine the interrelationship between reading skill and cognitive style in a broader context.

\section{REFERENCES}

[1] Abraham, R. G. (1985). Field independence /dependence and the teaching of grammar. TESOl Quarterly, 19, 689-702.

[2] Abu Romman, S. (2005). The effect of match/mismatch of teaching -learning styles on secondary stage students' achievement in English in Jordan. Unpublished Ph. D. dissertation, Amman Arab University for Graduate Studies, Jordan.

[3] Altun, A. (2003). The relationship between teacher trainees' attitudes toward computers and their cognitive styles. Turkish Online Journal of Educational Technology, 2(1). Retrieved July 5, 2013 from http://www.tojet.sakarya.edu.tr/archive/v1i2/arif3.htm. 
[4] Brown, H. D. (1994). Principles of language learning and teaching. Sanfrancisco: Prentice Hall.

[5] Clark, H. T., \& Roof, K. D. (1988). Field dependence and strategy use. Perceptual and Motor Skills, 66, 303-307.

[6] Carrell, P. L., \& Eisterhold, J. C. (1983) "Schema theory and ESL reading pedagogy". In P. L. Carrell, J., Devine, \& D. E. Eskey (Eds.), Interactive approaches to second language reading. Cambridge: CUP.

[7] Chaplle, C. (1988). Field independence: A source of language test variance. Language Testing, 5(1), 62-82.

[8] Daoud, J. (2008). The effect of students' perception and matching instruction with cognitive style on secondary stage students' achievement in English literacy skills in Jordan. Unpublished Ph. D. dissertation, Amman Arab University for Graduate Studies, Jordan.

[9] Davey, B. (1990). Field dependence-independence and reading comprehension questions: Task and reader interactions, Contemporary of Experimental Education, 52, 119-206.

[10] Dooley, P. B. (1976). The relation of field independence, $\mathrm{m}$ space, and intelligence in efficient and inefficient readers. Dissertation abstracts international, 37, 1465- A.

[11] Dwyer, F. M., \& Moore, D. M. (1995). Effect of color coding and test type (visual/verbal) on students identified as possessing different field dependence levels. The Journal of Psychology, 125(6), 677-680.

[12] Dyer, J. E., \& Osborne, E. W. (1996). Effects of teaching approach on achievement of agricultural education students with varying learning style. Journal of Agricultural Education, 3, 43-51.

[13] El-Koumy, A. (2001). The effect of matching versus mismatching instructional approaches with cognitive styles on EAP students' achievement in reading comprehension. Proceedings of the 7th EFL Skills Conference. The American University in Cairo: CACE.

[14] Fehrenbach, C. R. (1994). Cognitive style of gifted and average readers. Roeper Review, 16(4), 290-292.

[15] Field, J. (2004). An insight into listeners' problems: Too much bottom-up or too much top-down? System, 32, 363-367.

[16] Foel, N. A., \& Fritz, R. L. (1994). Association of cognitive style and satisfaction with distance learning. Journal of Industrial Teacher Education, 33, 46-59.

[17] Gough, P. B. (1972). One second of reading. In J. F. Kawanagh \& I. G. Mattingley (Eds.), Language by ear and by eye. Cambridge, MA: MIT Press.

[18] Grabe, W. (1991). Current developments in second language reading research. TESOL Quarterly, 25, 375-405.

[19] Guisande, M. A. Paramo, M. F. Tinajero, C., \& Almeida, L. S. (2007).” Field dependence independence (FDI) cognitive style: An analysis of ntentional functioning". Psicothema, 19 (4), 572-577.

[20] Hamed Mahvelati, E., \& Mukundan, J. (2012). The role of cognitive style in the collocation knowledge development of Iranian EFL learners through input flood treatment. English Language Teaching, 5(10), 105-117.

[21] Joffe, R. T. (1987). Reflective- impulsivity and field dependence/ independence as factors in the reading achievement of children with reading difficulties. Dissertation abstracts international, 48, 876- A.

[22] Liu, M., \& Reed, W. M. (1994). The relationship between the learning strategies and learning styles in a hypermedia environment. Computers in Human Behavior, 10, 419-434.

[23] Miller, G. (1997). Are distance education programs more acceptable to field-independent learners? (ERIC Document Reproduction Service No. ED 409854.)

[24] Paran, A. (1996). Reading in EFL: Facts and fictions. ELT Journal, 5(1), 25-34.

[25] Salmani-Nodoushan, M. A. (2006). Does field independence relate to performance on communicative language tests? Manager's Journal of Educational Technology, 3(3), 79-85.

[26] Shalbafan, K. (1996). On the role field dependence/field independence in Iranian EFL learners' writing ability. Unpublished master's thesis, University of Tehran.

[27] Simonson, M. R. (1985) Persuasion: Five studies dealing with the relationships between media, attitudes, and learning style . (ERIC Document Reproduction Service No. ED 256 337.)

[28] Škudienè, V. (2002). A comparison of reading models, their application to the classroom and their impact on comprehension. Studies about Languages, 2, 94-98.

[29] Sudzina, M. (1993). Educational psychology applications. In T. Graves (Ed.), Cooperative learning and preservice teacher education. Cooperative Learning, 13(3), 32-35.

[30] Swaffar, J. K., Arans, K. M., \& Byrnes, H. (1991). Reading for meaning. Integrated approach to language learning. N Jersey: Prentice Hall.

[31] Tinajero, C., \& Paramo, M. F. (1997). "Field dependence / independence and academic achievement: A re-examination of their relationship", Educational Psychology, 67, 199-212.

[32] Tsui, A. B. M., \& Fullilove, J. (1998). Bottom-up or top-down processing as a discriminator of L2 listening performance. Applied Linguistics, 19(4), 432-451.

[33] Wasilewski, J. (2009). Contemporary understanding of the reading process and reading strategies used by ESOL learners while reading a written discourse. Humanising Language Teaching, 4, 145-159.

[34] Witkin, H. A., Oltman, P., Raskin, E., \& Karp, S. (1971). A manual for the embedded figures test. Palo Alto, CA: Consulting Psychologist Press.

[35] Xu. W. (2011). Learning styles and their implications in learning and teaching. Theory and Practice in Language Studies, 1(4), 413-416.

[36] Yaghoubi, R. (1994). The relationship between field-independent/field-dependent cognitive style Persian students and their English language proficiency. Unpublished master's thesis, Allameh Tabatabaii University, Iran.

[37] Zhang, L. F. (2004). Field-dependence/independence: Cognitive style or perceptual ability? Validating against thinking styles and academic achievement". Personality and Individual Differences, 3, 1295-1311. 
Azar Hosseini Fatemi, assistant professor in TEFL, is the head of Department of English, Ferdowsi University of Mashhad, Mashhad, Iran. Her areas of interest include issues in second language teaching and learning.

Vahideh Sadat Vahedi is the faculty member at Islamic Azad University, Qaenat branch, Qaenat, Iran. She is a PhD candidate in Applied Linguistics at Ferdowsi University, Mashhad, Iran. She received her M.A. degree in English language teaching from Alzahre University, Tehran, Iran in 2006, and she also got the B.A. degree in English language and literature from Ferdowsi University of Mashhad, Mashhad, Iran in 2006. Her areas of research include applied linguistics, Anxiety in EFL learning, and CALL. She has presented and published several articles in international conferences and journals.

Zari Sadat Seyyedrezaie received her BA in English language and literature from Zahedan University, Iran. Then she received her MA in TEFL from Islamic Azad University, Science and Research Branch in Iran. She started her Ph.D at the University of Mashhad in 2012. She has presented some papers in International conferences in different countries and also published some papers in international journals. Her major areas of interest are English testing, evaluation, and language teaching methodology. 